\title{
Gradual Retirement and Lengthening of Working Life
}

\author{
Pekka Ilmakunnas \\ Helsinki School of Economics and HECER \\ and \\ Seija Ilmakunnas \\ Finnish Centre for Pensions
}

Discussion Paper No. 121

October 2006

ISSN 1795-0562

HECER - Helsinki Center of Economic Research, P.O. Box 17 (Arkadiankatu 7), FI-00014 University of Helsinki, FINLAND, Tel +358-9-191-28780, Fax +358-9-191-28781,

E-mail info-hecer@helsinki.fi, Internet www.hecer.fi 


\section{Gradual Retirement and Lengthening of Working Life*}

\section{Abstract}

In order for the part-time pension to make sense economically, it should extend the length of the working career. An interesting question is also whether the timing of retirement and willingness to work after retirement are related. We use data on the aspirations of individuals regarding their old-age retirement behaviour to estimate a multivariate probit model with three binary dependent variables: partial retirement, planning to continue working beyond age 63, and planning to continue working while on retirement. The model is estimated using simulated maximum likelihood.

The probability of being on part-time pension increases with the length of working career, but decreases with wage. It is positively related to an indicator of chronic illness. Age has a positive effect on the probability of thinking about continuing working after age 63 , which is natural since in the older age cohorts those preferring to retire early have already done that. Higher wage and private pension insurance have a negative effect on the probability of continuing to work, while the level of education increases it. Women and those having mental strain in their job are less likely to postpone retirement. The probability of continuing work while retired is difficult to predict. Only good self-assessed health seems to play an important role in this decision-making. Being on partial retirement has no positive impact on the probability of preferring to stay longer at work. This gives support to the worries that partial retirement is a tool that helps in increasing the labour force participation of the aging labour force, but at a relatively high cost.

JEL Classification: J260, J140

Keywords: part-time retirement, retirement age, retirement expectations.

Pekka Ilmakunnas

Department of Economics

Helsinki School of Economics

P.O. Box 1210

FI-00101 Helsinki

FINLAND

e-mail: pekka.ilmakunnas@hse.fi
Seija IImakunnas

Finnish Centre for Pensions

FI-00065 Eläketurvakeskus

FINLAND

e-mail: seija.ilmakunnas@etk.fi

* Presented at the Workshop on Labour Markets and Demographic Change in Rostock and at FISS Conference in Sigtuna. We are grateful to the participants in these conferences, as well as to Tuulia Hakola and Eila Tuominen for useful comments. 


\section{Introduction}

This paper deals with empirical evidence on gradual retirement, which is a topical issue in shaping the ageing policies. Gradual retirement has provoked high hopes because of two reasons. Firstly, it is considered to reflect the preferences of the employees. Winding down the work commitments during a period of time is widely considered to be a more desired option than a single abrupt departure from the full-time job. Combining part-time work with partial pension is one way to achieve this preferred state. Secondly, gradual retirement has also been seen as an important tool in postponing the retirement age and making the pension systems more sustainable. In this reasoning, reduced hours help individuals to keep their work capacity and work motivation, which in turn enables the longer working careers.

Accordingly, it is natural that a policy with two simultaneous positive effects is high on the agenda. However, it is not certain that the policy to encourage gradual retirement will automatically be successful. For instance, it can fail if the gradual retirement can only be achieved by too costly measures. One risk is that the subsidies for reduced hours (in the form of partial pension) need to be very high in order to make gradual retirement a real option for a sufficiently large share of ageing employees. The OECD, for instance, has pointed out that one has to get the incentives right. The Finnish part-time pension (available currently at ages 5867) has been used as an example of a system with high subsidy for this extra leisure time. Accordingly, one has to set the benefits against the costs of the scheme.

In order for the part-time pension to make sense economically, it should extend the length of the working career. This holds true especially when the replacement rates of the part-time pension are relatively high. Combining pension benefits and wage is also possible after retirement to the old-age pension. Work after retirement is encouraged in Finland, where since the pension reform in 2005 new pension rights can be accrued when working after retirement. An interesting question is whether the timing of retirement and willingness to work after retirement are decisions related to each other.

The analysis in this paper is carried out in the Finnish context, where the employees have a subjective right to choose their old-age pension retirement age between ages 63 to 68 . Also in the case of part-time pension the individual takes the initiative, subject to the employer's approval. This kind of setting emphasises individual decision-making subject to incentives 
given by the pension system. It also makes it natural to examine the aspirations of the individuals regarding their future old-age retirement behaviour.

The effects of many pension reforms will come true only gradually in the future after rather long transition periods. However, the need to estimate these effects is often immediate. These estimates are needed when one wants to assess, for instance, whether the likely effects on the effective retirement age large enough. Since no actual observations on retirement behaviour after the reform are available one has to rely on retirement expectations. Accordingly, retirement expectations have been analyzed in several earlier papers, mostly in the US, but also in European countries.

One issue in this field of research has been comparison of retirement expectations and realizations (e.g. Bernheim, 1989, Disney and Tanner, 1999, Mastrogiacomo, 2003, BenítezSilva and Dwyer, 2005). It has been found that the expectations indeed predict realizations. ${ }^{1}$ Another issue that has been investigated is whether changes in pension incentives or in other circumstances, like health, influence expected retirement behaviour (e.g. Chan and Stevens, 2004, Botazzi et al., 2005, McGarry, 1999). The results of these studies show that retirement expectations are revised after policy changes or after changes in health status. In contrast to many of these studies we do not have longitudinal data on expected retirement behaviour, nor do we have data on realizations. However, we have several measures for planned or already realized forms of gradual retirement behaviour in a cross-sectional data set and we can examine their determinants and interactions.

There is growing interest in gradual retirement, but the number of earlier studies is still rather limited. Furthermore, the concept 'gradual retirement ${ }^{2}$ itself is not necessarily a very clear one. Here we define gradual retirement as the following process: the individual reduces his or her working hours at the later stage of the working career at the same time receiving both earnings and pension (either partial of full pension). More specifically, in our case gradual retirement takes place when the individual takes the part-time pension prior to full-time retirement (at the same time reducing the working hours roughly to half, typically in the

\footnotetext{
${ }^{1}$ Some economists have mixed feelings about using data on individuals' perceptions and intentions (e.g. Bertrand and Mullainathan, 2001). On the other hand, there exists evidence that intention variables indeed predict actual behaviour. In psychological literature this is justified by the theory of planned behaviour (e.g. Ajzen, 1991).

${ }^{2}$ Sometimes concepts phased or partial retirement are used instead of gradual retirement. One should not confuse the concept 'gradual retirement' with the concept 'flexible retirement' where workers are given a range of ages over which they can retire so that the transition from work to retirement remains a single abrupt departure.
} 
current job). Gradual retirement takes also place when the individual chooses to work (at least somewhat) even after he or she has taken the full-time pension and has quitted the career job.

Institutions relevant to gradual retirement vary remarkably. In some countries the pension system may include elements that are tailored to encourage gradual retirement, while the opposite is true in other countries. For instance, special part-time pensions may be designed to be substitutes for full-time early retirement. Furthermore, working while on old-age pension may be encouraged by removing earnings tests in these schemes and by giving new pension credits for the earnings received after retirement. Workers may also be permitted to draw a portion of their standard old-age pension early while still working. If the pension system includes elements listed above, the popularity of gradual retirement is likely to be noticeable.

The institutions are naturally related to the relevant research questions. The US literature has paid attention to the role of so-called 'bridge jobs'. Bridge jobs are held subsequent to career employment and prior to retirement. According to Ruhm (1990) and Delsen and RedayMulvey (1996) they have been rather common, and often they have been part-time. It has been difficult to reduce working hours in the career job (Abraham and Houseman, 2004). Thus, an employee wishing to reduce working hours needs typically to find another job, which is likely to be one reason for the large number of bridge jobs.

The US type of "gradual retirement" is not based insurance-based subsidies to older workers reducing their working hours. According to the OECD (2006), in Finland and Sweden parttime pensions have been generous enough to attract a large share of older workers to use them as a bridge to retirement. ${ }^{3}$ This paper deals with an institutional setting where gradual retirement is subsidised. The relevant question is then to ask whether the subsidies in question help to raise the effective old-age retirement age.

The structure of the paper is as follows. In section 2 we describe the institutional setting. In Section 3 we describe the data set and variables that we are using. In section 4 we present estimation results and Section 5 concludes the paper.

\footnotetext{
${ }^{3}$ Some analysts confirm the conclusion that the popularity of the former Swedish part-time pension is explained by its generosity. According to Wadensjö (1996) high replacement rates of the scheme help to understand why it became more popular than in other countries. Latulippe and Turner (2000) also argue that the number of workers taking the partial pension option has been higher during periods when replacement rate was higher and/or unemployment rate was higher.
} 


\section{Institutional aspects of the Finnish pension system}

\subsection{Part-time pension and early exit policy}

In order to keep the pension systems sustainable, economically active life span has to adapt to longer life spans. In countries with many early retirement pathways these challenges have been most urgent, and Finland is one of those countries. Accordingly, early exit arrangements have witnessed many reforms during the last decade (see Ilmakunnas \& Takala, 2005).

There are four types of early exit pathways. These are the voluntary early retirement path (early old-age pension), the disability path (disability pension and individual early retirement pension), the unemployment path (unemployment pension) and the gradual retirement path (mainly part-time pension) (Gould and Saurama, 2004). ${ }^{4}$ The effective retirement age is currently 59.1 years, which clearly indicates that these early exit arrangements are widely used.

However, the change from the policy promoting early retirement to the policy promoting staying at work has been rapid. Most early retirement schemes (individual early retirement pension, early old-age pension and part-time pension) were introduced only in the late $1980 \mathrm{~s}^{5}$ Already in the 1990s early retirement schemes were targets for several changes that aimed at reducing their popularity. Accordingly, the "golden era" of early retirement policies was actually quite short in Finland. ${ }^{6}$

It is interesting to consider the role of the part-time pension in this rapid policy shift. Part-time pension is granted to an employed person who changes from full-time work to part-time work (full-time working hours are reduced to 16-28 hours a week). The part-time pension benefit is 50 per cent of the difference between full-time and part-time earnings. The pension reform in 2005 increased the eligibility age by two years (from 56 to 58 ) for persons born after $1946 .^{7}$

This scheme enabling gradual retirement has witnessed many reforms during its 20-year history. First the lower age limit in the private sector was 60 years. Its motivation was to enable

\footnotetext{
${ }^{4}$ After a transition period the unemployment pension and the individual early retirement pension are abolished as a part of the pension reform 2005.

5 The part-time pension scheme was introduced in 1987 in the private sector and the public sector followed in 1989. The corresponding Swedish scheme was in many respects used as a model for it (Takala, 2002).

${ }^{6}$ In the pension reforms since the early 1990s the age limits for the early retirement schemes have been raised, some schemes are totally abolished and also the incentives have been modified so that the schemes have become less generous both for the employees and the employers.

${ }^{7}$ Furthermore, the old-age pension accrual on the part-time pension time (non-working time) is smaller than before (reduction from $1.5 \%$ to $0.75 \%$ ).
} 
smooth transition from work to retirement and to make more room for individual circumstances in retirement decisions. Accordingly, it was also considered as a scheme that makes the work commitments meet the reduced work capacity during the later years in the labour market. Furthermore, it was expected that the use of part-time pension would reduce the use of the disability pensions.

In its early years, the popularity of this scheme was low, much lower than expected when creating the scheme. Accordingly, changes were introduced in order to make it more widely used. The age limit was first lowered from 60 years to 58 years in 1994 and later, in 1998, to 56 years. Secondly, from 1994 onwards, new pension rights were accrued also on the basis of the difference between the full-time wage and the part-time wage (in addition to the part-time earnings). Thus, using part-time pension did not diminish the level of old-age pension. The part-time pension was seen as a tool to lengthen the working careers, and its generosity was increased at the same time as the other early retirement schemes started to face restrictions.

These changes made the scheme much more popular since the late 1990s. Furthermore, large part of the rapid increase in the employment rates in the older age groups is related to this scheme. In the age group 60-64 the number of part-time pensioners (and accordingly part-time workers) has risen remarkably, but the employment rate for those working full-time has risen only a little during the last ten years. Currently the share of part-time pensioners is nearly 25 per cent among the employed in the age group, up from a level of 9 per cent ten years earlier. Also for the age group 55-59 part-time pensions have played an important role. Naturally, the increases in the use of part-time pensions and part-time work imply that the number of hours worked has grown less rapidly than the number of the employed.

Thus, increased use of part-time pensions has been one important element behind the good employment performance among older workers, especially in the age group 60-64. But it is also important to consider the costs of this development. In evaluating the economic desirability of the scheme one has to consider many elements. First, financing these pensions implies a direct cost to the pension system. Second, the reduction in working hours also affects the pension finances negatively. On the other hand, part-time pensions may lengthen the working careers. This mitigates the negative effect of the reduced working hours. Furthermore, for some persons 
the alternative is not full-time work but some other early retirement pension. In those cases the economic effect is positive. ${ }^{8}$

Figure 1: Employment rate and part-time pension (age groups 55-59, 60-64)

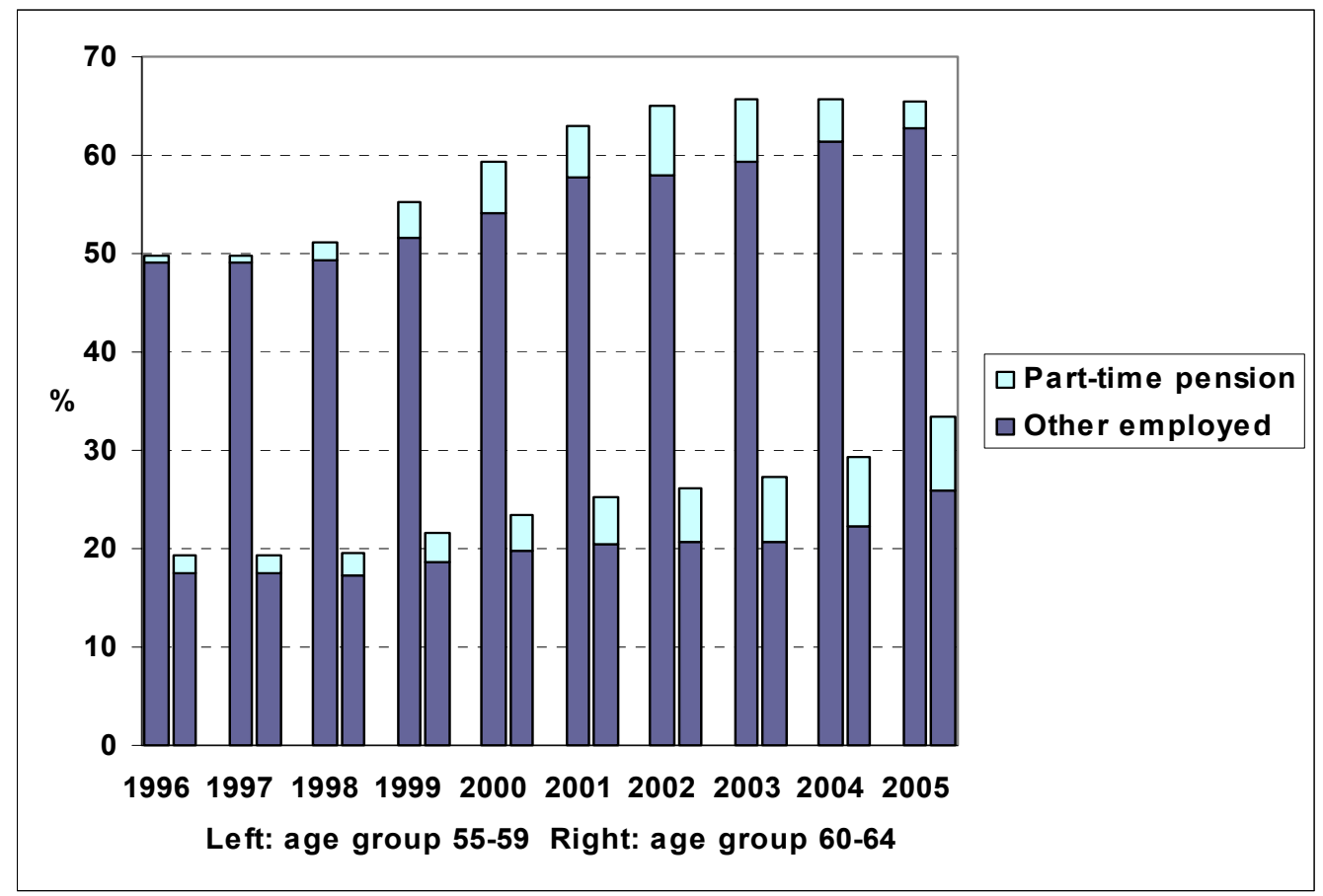

Source: Labour Force in Finland, Statistics Finland \& Pension Statistics, Finnish Centre for Pensions

In the current institutional setting other early retirement schemes (except disability pension) are being abolished. This implies that the alternative for the use of part-time pension is less often full-time retirement. Accordingly, it becomes an even more important question whether the longer working careers (due to part-time pension) can compensate the negative effect of reduced working hours at the later stage of the working life. In this paper we try to investigate whether and to what extent the use of part-time pension helps to postpone retirement. Prior to this investigation we consider the rules for the old-age pension.

\subsection{Flexible old-age pension}

The formerly fixed retirement age has become flexible. Thus, the role of individual decisionmaking (or optimization) has been increased in the timing of retirement. Currently an employee

\footnotetext{
${ }^{8}$ In this paper we analyze whether the part-time pension helps to postpone the retirement age beyond the lower age limit of the so-called flexible old-age retirement age. There might also be a positive effect operating at younger ages. It is not considered here.
} 
who has turned 63 can decide him- or herself the date of commencement of the pension: he or she may retire on an old-age pension between the ages 63 and 68. There is a sharp increase in the accrual rate at the age of 63 (from 1.9 per cent to 4.5 per cent), which is the incentive to persuade individuals to postpone the retirement (after the age of 63). Furthermore, there is no cap on the replacement rate in the reformed pension system (in the old system the pension could not exceed 60 per cent of the highest wage). Accordingly, employment at older ages has become more effective way to increase one's level of pension.

There is also an option to take the pension at the age of 62 with a reduction in the level of the pension (the reduction rate being 0.6 per cent per month, i.e. 7.2 per cent at the most). There is also the possibility to postpone the retirement beyond the age of 68 . The pension is then increased by 0.4 per cent for each month for which it is postponed.

Employment at the older ages is also encouraged by making it more beneficial to combine an old-age pension with work. A person drawing an old-age pension may work and have earnings without limitations. Furthermore, new pension rights are then accrued up to the age of 68 , the accrual rate being 1.5 per cent (instead of 4.5 per cent). This new pension accrual is added up to the former old-age pension at the age of 68 .

Also those on part-time pension can choose themselves when they stop working altogether and start to draw the full-time pension within the age bracket 63-68. Furthermore, the part-time pensioners born in 1946 or earlier can retire on an early old-age pension between the ages 60 and $62 .^{9}$

\section{Data set and variables}

Our basic data set is the Quality of Work Life Survey (QWLS) of Statistics Finland from year 2003 (Lehto and Sutela, 2005). The initial sample for QWLS is derived from a monthly Labour Force Survey (LFS), where a random sample of working age population is selected for a telephone interview. The QWLS is based on a sample of LFS respondents in October and November 2003 who were 15-65 old wage and salary earners with normal weekly working time of at least five hours. The sample consists of over 4000 individuals. We concentrate on

\footnotetext{
${ }^{9}$ If the person on the part-time pension retires to an old-age pension between the ages 60 and 62 , the reduction for early retirement is calculated in accordance with the old rules from the age of 65 (the reduction rate being $0.4 \%$ per month). This early retirement is likely to be economically unwise, since at the age of 63 he or she may retire on old-age pension with no reductions made in old-age pension.
} 
those QWLS participants who are over 56, but under 64 years old. ${ }^{10}$ The data set includes 398 such individuals, but because of missing observations on some variables, the data set used in the econometric analysis has 382 observations.

QWLS includes questions on the personal characteristics of the respondents, and a large set of questions on perceived working conditions. In the 2003 survey there were special questions on the pension plans of the respondents. These are our key variables of interest. Statistics Finland supplements QWLS with information from the LFS, such as working time and exact labour market status. Supplementary information on e.g. the employer, the level of education of the respondents and their taxable earnings is matched from various registers maintained by Statistics Finland. In addition, the Finnish Centre for Pensions has supplemented the QWLS data set with register information on e.g. working career, some pension benefits, and part-time pensions. $^{11}$

Our interest centres on three dependent variables and their relationships. First, we have a binary indicator PARTIAL_RETIREMENT for those who are on part-time pension (based on register information) or who have already applied for such pension (based on the survey). Second, we have information from the survey on the preferred retirement age. As is common in this kind of surveys, the answers tend to be bunched to certain years, in our case to 60, 63, and 65 (see Figure 2). One interpretation of this is that the answers do not relate to mean but rather to most likely retirement age (Bernheim, 1989). We have therefore formed a binary indicator RETIREMENT_OVER_63 for those whose preferred retirement age is over 63 years (which is the lower age limit of the so called flexible retirement age and used to be the common retirement age for many individuals in the state pension system). ${ }^{12}$ Thirdly, we have a binary indicator RETIRE_AND_WORK for those who are ready to continue working while they are retired.

\footnotetext{
${ }^{10}$ For this sample the rules for the part-time pension are the same (e.g. the eligibility age). The choice of the upper age limit is motivated by the fact that we are interested in the decision to retire on old-age pension at the age of 64 or over.

${ }^{11}$ Also Forma et al. (2005) have used the same data to analyse the intentions of older workers to continue working. Their interest is concentrated to the desired old-age retirement age instead of gradual retirement. Karisalmi (2005) uses the data to analyze the relationship between atypical work and retirement aspirations.

${ }_{12}$ When discussing the robustness of our results we also model retirement age as an ordered variable: below 63, 63, and above 63. Disney and Tanner (1999) have used a similar cut-off. They also discuss the role of "don't know" answers and argue that answering this way may be a rational response when there is lots of uncertainty, e.g. because there are still many years to retirement. This does not seem to be a problem in the present study, since we concentrate on over 56 years old persons and in our sample the share of "don't know" answers is only 1.5 per cent among them (these answers are not included in Figure 2).
} 


\section{Figure 2. Preferred retirement ages}

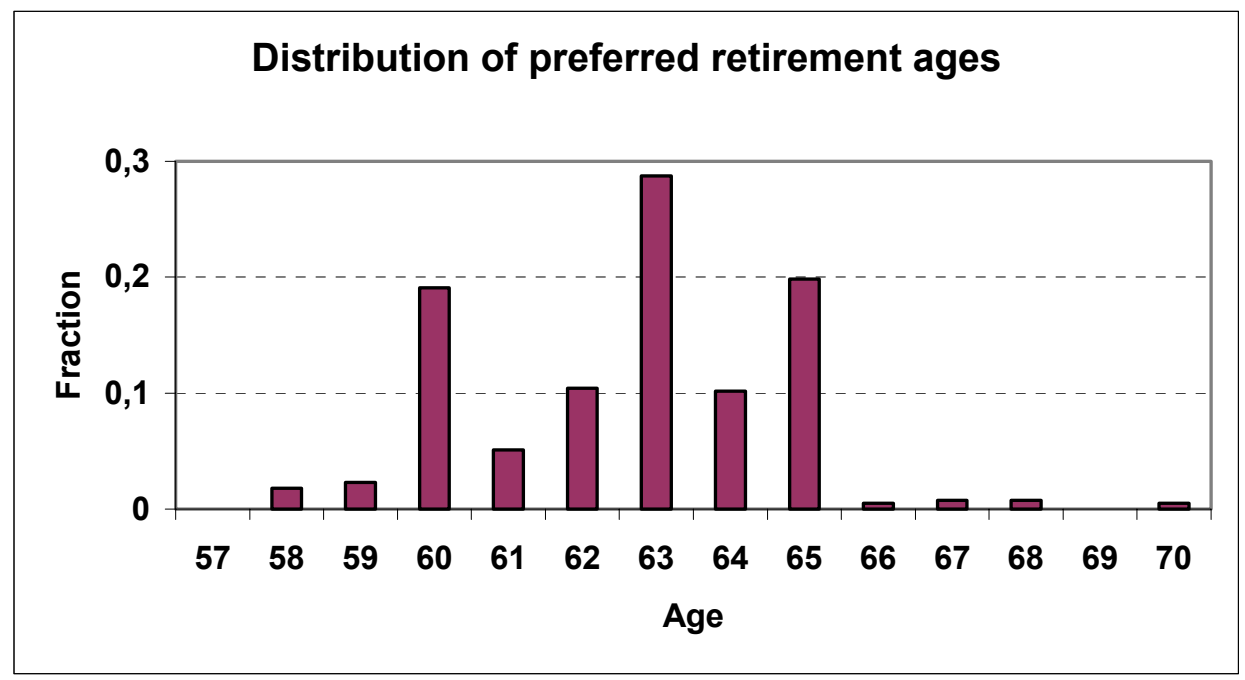

Note: Respondents are in age group 57 to 63

Source: Quality of Working Life Survey

These three indicators are likely to affect each other. In particular, to evaluate the effects of partial retirement it is essential to examine whether it lengthens the time to full retirement, i.e. whether PARTIAL_RETIREMENT affects RETIREMENT_OVER_63 positively. Furthermore, the relationship between retirement age and continuing work while retired is interesting.

As explanatory variables we use various characteristics of the individual, job, and employer (a detailed description of all the variables is in Appendix 1). The variable CAREER measures the years of work experience (based on pension registers). Long working career tends to increase the willingness to use part-time pension. It may also make the individual more likely to choose a lower rather than higher old-age retirement age within the "window" of flexible retirement age (63-68). Basically long working career can decrease the motivations to further continue one's career since working capacity may decrease over time in many occupations. It may also increase the personal feeling that one has already worked long enough in the labour market, and it is fair to be able to retire. Long work career naturally also tends to increase the accrued pension, and thus make it economically possible to retire earlier (the income effect). Since we control for self-assessed working capacity (CAPACITY), CAREER is likely then to catch the other effects listed above. For those who have a temporary employment relationship we use an indicator TEMPORARY. Since the part-time pension is subject to the employer's approval, it is unlikely that temporary employees have opportunities for using it. 
Age group dummies AGE_i are defined for groups $i=57, \ldots, 63$. They also take into account the natural selection effect in the older age cohorts, i.e. those preferring to retire early have already done that and selected themselves out of the sample. We therefore expect there to be positive age effects on plans to retire at an age over 63.

We measure education by dummies EDUCATION1 to EDUCATION4 for four educational levels. A priori we can expect more educated individuals to be prepared to work longer. We have indicators for females (FEMALE) and those who are married or cohabiting (dummy MARRIED). Being married may affect retirement decisions when both spouses want to retire at the same time. Unfortunately, our data do not have information on the age or the labour market status of the spouse.

Earnings are taken into account by 4 wage group dummies (WAGE_i, i=1,..,4). Earnings have two kinds of effects. On one hand, higher earnings encourage people to continue working (substitution of leisure and consumption over the life cycle), but on the other hand people with higher incomes can afford to retire earlier (income effect). The earnings information is based on self-reported monthly earnings groups from the survey. For those already on partial retirement we have adjusted the wage groups, since the current wage does not reflect earnings potential in full-time work. ${ }^{13}$

Working in physically or mentally unfavourable conditions (indicators HEAVY_PHYSICALLY and HEAVY_MENTALLY, respectively) is expected to have a positive impact on partial retirement and a negative impact on the probability of continuing to work after age 63. Also variables related to poor health can be expected to have similar effects. We measure health by a dummy for chronic illness (ILLNESS) and using a variable for selfassessed work capacity (CAPACITY, measured as a score from 0 to 10). The former should have a negative and the latter a positive effect on the probability of continuing to work after age 63. The survey also has a question on self-assessed health, but we consider these two indicators more reliable.

\footnotetext{
${ }^{13}$ The wage variable is based on self-reported monthly wage groups. For those who are on partial retirement the variable gives the part-time earnings. Instead of these earnings, we would want to measure the potential earnings were the individual to continue in full-time work. We use the information on the amount of the part-time pension to calculate the wage level (the amount of pension is $50 \%$ of the difference between full-time and part-time earnings). We have assumed that part-time earnings are half of full-time earnings. In practice this needs not to be the case since the reduction in working hours and earnings can vary within limits (full-time hours are reduced to 16-28 hours). Furthermore, for some part-time pensioners the level of the pension is missing. For them the wage measure is based on the annual wage income of the previous year from the tax registers (divided by 12).
} 
There are some differences between the private and public sectors since previously negotiated lower retirement ages have been protected in the pension reform (during a transition period).To account for these differences, we add dummy variables for belonging to private pension system (PRIVATE_SYSTEM). There is also an indicator for private pension insurance saving (OWN_PLAN). Having own private pension insurance is an indicator for planning to retire earlier, although it can also be used for compensating an otherwise low pension after normal retirement age. In principle, one can think that private insurance is endogenous, since same kind of individual factors that affect the likelihood of having a private insurance may affect the likelihood of e.g. staying longer in working life. On the other hand, the decision on acquiring a private insurance has already been made before the survey.

Employer-related variables include indicators for the use of "unemployment pension pipeline" in the firm (PIPELINE) ${ }^{14}$ and an indicator for small firms (SMALL_PLANT). If the employer uses the unemployment pension pipeline for the employees in mid 50's, it is likely that there is a need for reductions in the number of personnel and hours worked. It is then likely that at the same time the older employees are encouraged to use a partial retirement option so that further lay-offs could be avoided. The pipeline is also likely to affect the willingness (and opportunities) of continuing work after age 63. On the other hand, use of the pipeline should have no impact on plans to work while retired. Finally, small firms are likely to have more difficulties in adjusting their labour input when some employees are on partial retirement (see e.g. Latulippe and Turner 2000). ${ }^{15}$ This is taken into account with a dummy SMALL_PLANT for work places with less than 10 employees, which is expected to have a negative effect on the probability of being on part-time pension.

\footnotetext{
${ }^{14}$ Unemployment pension pipeline refers to the following arrangement: those who have become unemployed at the age of 55 or over have been able to receive earnings-related unemployment benefit until the age of 60 , after which they have been entitled to unemployment pension. In pension reform 2005 unemployment pension will be removed, but extended unemployment benefits are paid for those becoming unemployed at the age of 57 or more until they are eligible for old-age pension.

${ }^{15}$ In Finland there is partial experience rating in disability pensions and unemployment pensions for large firms, while part-time pensions lack that particular feature. Thus, large firms are likely to be more inclined to use parttime pensions when there is need for downsizing.
} 


\section{Models and estimation results}

\subsection{Basic results}

Our aim is to explain the prevalence of the three indicators of retirement with the characteristics of the individual, job characteristics, and variables that are related to incentives for lengthening the working life. Since we have formed binary indicators for them, we will use probit models. It is possible that these indicators are related with each other. First, the same unobserved characteristics of the individuals may affect all three decisions or plans, making the error terms of the individual models correlated with each other. Secondly, the phenomena may be more directly related through simultaneity. We therefore model the variables as a multivariate probit system.

Our data set is a cross-section, but we can still hypothesize a recursive structure in the process how the individuals are formulating their retirement plans and aspirations. The decision on part-time retirement is made first; in fact, it has already been made before the survey. Given this decision, the individuals anticipate whether they plan to work beyond the age 63. Given their anticipated retirement age, they indicate whether they plan to continue working while on retirement. The model is recursive, since previously made decisions or plans affect the subsequent ones, but there is no feedback from the later decisions to previous ones. Because of the recursive structure the model can be estimated as a standard multivariate probit model with maximum likelihood ${ }^{16}$.

Exclusion restrictions are not needed for identification in this kind of probit models (Wilde, 2000), but it may still be a good practice to use some restrictions. ${ }^{17}$ First, we argue that working in a small firm is likely to affect the propensity to take partial retirement, but not the other decisions or plans. Second, people working on a temporary contract should have fewer opportunities for taking part-time pension, but it need not affect the other decisions. Third, having voluntary private pension insurance can affect decisions on part-time retirement and aspired retirement age, but it is not likely to affect plans to continue working while retired (at least when wage income is controlled). Fourth, the personnel policies of the current employer, measured by PIPELINE, and the current working conditions, HEAVY_PHYSICALLY and HEAVY_MENTALLY, should not affect plans to continue working while on retirement.

\footnotetext{
${ }_{17}^{16}$ The model is a special case of the model proposed by Heckman (1978). It is discussed e.g. in Greene (2003).

17 Using the restrictions improves the validity of tests of exogeneity of the potentially endogenous explanatory dummy variables (essentially, tests of whether the correlations of the errors of the probit models are zero) when the distributional assumptions are misspecified (see Monfardini and Radice, 2006).
} 
Hence, our exclusion restrictions are that SMALL_PLANT and TEMPORARY are excluded from the equations for RETIREMENT_OVER_63 and RETIRE_AND_WORK, and the variables OWN_PLAN, PIPELINE, HEAVY_PHYSICALLY, and HEAVY_MENTALLY are excluded from the equation for RETIRE_AND_WORK.

Formally, we have three latent variables $\mathrm{y}_{1}{ }^{*}, \mathrm{y}_{2} *$ and $\mathrm{y}_{3} *$ and their observation rules (1(.) denotes an indicator function):

$\mathrm{y}_{1} *=\mathrm{X}_{1} \beta+\varepsilon_{1}$

PARTIAL_RETIREMENT $=\mathbf{1}\left(\mathrm{y}_{1} *>0\right)$

$\mathrm{y}_{2} *=\alpha_{2}$ PARTIAL_RETIREMENT $+\mathrm{X}_{2} \beta+\varepsilon_{2}$

RETIREMENT_OVER_63 $=\mathbf{1}\left(\mathrm{y}_{2} *>0\right)$

$\mathrm{y}_{3} *=\alpha_{3}$ RETIREMENT_OVER_63 $6 \mathrm{X}_{3} \beta+\varepsilon_{3}$

RETIRE_AND_WORK $=\mathbf{1}\left(\mathrm{y}_{3} *>0\right)$

$\varepsilon_{1}, \varepsilon_{2}$, and $\varepsilon_{3}$ are the errors and $\mathrm{X}_{1}, \mathrm{X}_{2}$, and $\mathrm{X}_{3}$ are the explanatory variables (including constant terms). The endogenous variables have a recursive structure and the exclusion restrictions are incorporated into the X's. The three-equation multivariate probit model is estimated with simulated maximum likelihood (e.g. Cappelari and Jenkins, 2003).

We cross-tabulate our dependent variables in Table 1. 23 per cent $(=91 / 395)$ of the individuals are on partial retirement or have applied for it, and 33 per cent $(=133 / 395)$ plan to continue working beyond age 63. The two variables, PARTIAL_RETIREMENT and RETIREMENT_OVER_63, are independent according to Pearson's chi-squared test and also their correlation is low. This is mainly a result of fairly similar share of those who plan to continue working beyond age 63 among those who are on partial retirement and among those who are not on partial retirement. 35 per cent intend to continue to do some work when on retirement. Among those on partial retirement this share is 28 per cent. The correlation of PARTIAL_RETIREMENT and RETIRE_AND_WORK is actually negative, as among those on partial retirement the plans to continue working are less common. Again, however, the independence of the variables cannot be rejected. Finally, the last part of the table shows that 
plans to continue working on retirement are more common among those who plan to retire after age 63. Also in this case, the variables are independent.

Table 1. Cross-tabulation of the dependent variables

\begin{tabular}{|c|c|c|c|c|c|}
\hline PARTIAL_RETIREMENT & ${ }_{0}$ RETI & T_OVER_63 & Total & Pearson $\chi^{2}(1)$ & $\begin{array}{l}\text { Tetrachoric } \\
\text { correlation }\end{array}$ \\
\hline 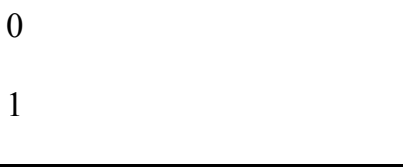 & $\begin{array}{l}203 \\
(66.78) \\
59 \\
(64.84)\end{array}$ & $\begin{array}{l}101 \\
(33.22) \\
32 \\
(35.16)\end{array}$ & $\begin{array}{l}304 \\
(100.00) \\
91 \\
(100.00)\end{array}$ & & \\
\hline Total & $\begin{array}{l}262 \\
(68.24)\end{array}$ & $\begin{array}{l}133 \\
(31.76)\end{array}$ & $\begin{array}{l}395 \\
(100.00)\end{array}$ & $\begin{array}{l}0.118 \\
(p=0.731)\end{array}$ & 0.033 \\
\hline PARTIAL_RETIREMENT & $\begin{array}{ll} & \mathrm{RE}^{\prime} \\
0 & \end{array}$ & $\mathrm{ND}_{1}$ WORK & Total & Pearson $\chi^{2}(1)$ & $\begin{array}{l}\text { Tetrachoric } \\
\text { correlation }\end{array}$ \\
\hline 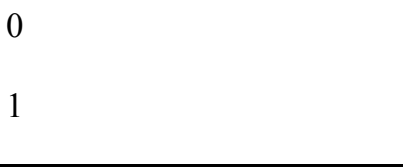 & $\begin{array}{l}190 \\
(62.50) \\
65 \\
(71.43)\end{array}$ & $\begin{array}{l}114 \\
(37.50) \\
26 \\
(28.57)\end{array}$ & $\begin{array}{l}304 \\
(100.00) \\
91 \\
(100.00)\end{array}$ & & \\
\hline Total & $\begin{array}{l}255 \\
(64.56)\end{array}$ & $\begin{array}{l}140 \\
(35.44)\end{array}$ & $\begin{array}{l}395 \\
(100.00)\end{array}$ & $\begin{array}{l}2.440 \\
(\mathrm{p}=0.118)\end{array}$ & -0.158 \\
\hline RETIREMENT_OVER_63 & $\begin{array}{ll} & \mathrm{RE} \\
0 & \\
\end{array}$ & $\mathrm{ND}_{1}$ & Total & Pearson $\chi^{2}(1)$ & $\begin{array}{l}\text { Tetrachoric } \\
\text { correlation }\end{array}$ \\
\hline $\begin{array}{l}0 \\
1\end{array}$ & $\begin{array}{l}173 \\
(66.03) \\
82 \\
(61.49)\end{array}$ & $\begin{array}{l}89 \\
(33.92) \\
51 \\
(38.51)\end{array}$ & $\begin{array}{l}262 \\
(100.00) \\
133 \\
(100.00)\end{array}$ & & \\
\hline Total & $\begin{array}{l}255 \\
(64.56)\end{array}$ & $\begin{array}{l}140 \\
(35.44)\end{array}$ & $\begin{array}{l}395 \\
(100.00)\end{array}$ & $\begin{array}{l}0.738 \\
(p=0.390)\end{array}$ & 0.074 \\
\hline
\end{tabular}

Note: the cross-tabulations are based on the subset of data for which all three variables are available.

Although unconditional cross-tabulations do not reveal significant relationships between the variables, we may still find relationships between them when we control for other variables. Table 2 shows the estimation results for the multivariate probit model. The results show that the probability of being on part-time pension decreases with wage. Both the length of working career and having a medically diagnosed illness increases the probability, but working capacity is insignificant. There seem to be no significant differences between men and women, between married and single individuals, or between the educational groups in their probability of being on part-time pension. There is some indication that part-time pension is less probable in small plants, but this effect is significant only at 10.5 per cent level. Interestingly, variables related to the pension incentives of the employee or the employer, OWN_PLAN and PIPELINE, are not significant.

As for retirement age anticipations, being already on part-time pension does not have a significant effect on the probability of thinking about continuing working after age 63 (the coefficient is even negative). This indicates that part-time pension does not lengthen the 
working career. Age has a positive effect on the probability of retiring after age 63, which is natural since there is a selection effect in the older age cohorts (those preferring to retire early have already done that). Those with the highest educational level have clearly highest probability of lengthening their working life. Females are less likely to continue working longer, but marital status does not have a significant effect. Income has a negative effect on the probability of postponing retirement, which indicates that the income effect dominates the substitution effect. Chronic illness decreases the probability of continuing the working life, but working capacity is not significant. Among the work conditions variables mental strains at work have a negative effect. Having private pension insurance decreases anticipated retirement age, as expected. Finally, the use of unemployment pension pipeline in the firm significantly decreases the probability that the employees would plan to continue working beyond the age 63.

Table 2. Multivariate probit estimation results

\begin{tabular}{|c|c|c|c|}
\hline & $\begin{array}{l}\text { PARTIAL } \\
\text { RETIREMENT }\end{array}$ & $\begin{array}{l}\text { RETIRE_- } \\
\text { OVER_63 }\end{array}$ & $\begin{array}{l}\text { RETIRE_- } \\
\text { AND_WORK }\end{array}$ \\
\hline PARTIAL_RETIREMENT & & $\begin{array}{l}-0.444 \\
(0.431)\end{array}$ & \\
\hline RETIRE_OVER_63 & & & $\begin{array}{l}0.207 \\
(0.391)\end{array}$ \\
\hline AGE_58 & $\begin{array}{l}-0.043 \\
(0.242)\end{array}$ & $\begin{array}{l}0.184 \\
(0.237)\end{array}$ & $\begin{array}{l}0.010 \\
(0.242)\end{array}$ \\
\hline AGE_59 & $\begin{array}{l}0.284 \\
(0.210)\end{array}$ & $\begin{array}{l}0.523 \\
(0.221)^{* *}\end{array}$ & $\begin{array}{l}-0.015 \\
(0.209)\end{array}$ \\
\hline AGE_60 & $\begin{array}{l}0.156 \\
(0.260)\end{array}$ & $\begin{array}{l}0.749 \\
(0.260)^{* * *}\end{array}$ & $\begin{array}{l}0.153 \\
(0.265)\end{array}$ \\
\hline AGE_61 & $\begin{array}{l}0.127 \\
(0.327)\end{array}$ & $\begin{array}{l}0.684 \\
(0.308)^{* *}\end{array}$ & $\begin{array}{l}-0.049 \\
(0.326)\end{array}$ \\
\hline AGE_62 & $\begin{array}{l}0.205 \\
(0.266)\end{array}$ & $\begin{array}{l}1.072 \\
(0.266)^{* * *}\end{array}$ & $\begin{array}{l}0.241 \\
(0.284)\end{array}$ \\
\hline AGE_63 & $\begin{array}{l}0.257 \\
(0.430)\end{array}$ & $\begin{array}{l}1.827 \\
(0.427)^{* * *}\end{array}$ & $\begin{array}{l}-0.079 \\
(0.478)\end{array}$ \\
\hline EDUCATION2 & $\begin{array}{l}0.224 \\
(0.181)\end{array}$ & $\begin{array}{l}0.361 \\
(0.186)^{*}\end{array}$ & $\begin{array}{l}0.238 \\
(0.181)\end{array}$ \\
\hline EDUCATION3 & $\begin{array}{l}0.016 \\
(0.235)\end{array}$ & $\begin{array}{l}0.355 \\
(0.230)\end{array}$ & $\begin{array}{l}0.022 \\
(0.221)\end{array}$ \\
\hline EDUCATION4 & $\begin{array}{l}0.205 \\
(0.345)\end{array}$ & $\begin{array}{l}0.719 \\
(0.320)^{* *}\end{array}$ & $\begin{array}{l}0.448 \\
(0.316)\end{array}$ \\
\hline FEMALE & $\begin{array}{l}0.123 \\
(0.177)\end{array}$ & $\begin{array}{l}-0.374 \\
(0.162)^{* *}\end{array}$ & $\begin{array}{l}-0.242 \\
(0.166)\end{array}$ \\
\hline MARRIED & $\begin{array}{l}-0.144 \\
(0.181)\end{array}$ & $\begin{array}{l}-0.204 \\
(0.184)\end{array}$ & $\begin{array}{l}-0.125 \\
(0.176)\end{array}$ \\
\hline WAGE_2 & -0.406 & -0.592 & -0.132 \\
\hline
\end{tabular}




\begin{tabular}{l|lll} 
& $(0.195)^{* *}$ & $(0.194)^{* * *}$ & $(0.192)$ \\
WAGE_3 & -0.471 & -0.463 & 0.098 \\
WAGE_4 & $(0.279)^{*}$ & $(0.282)^{*}$ & $(0.257)$ \\
CAREER & -0.866 & -1.049 & 0.476 \\
& $(0.417)^{* *}$ & $(0.386)^{* * *}$ & $(0.345)$ \\
ILLNESS & 0.041 & -0.014 & -0.005 \\
& $(0.018)^{* *}$ & $(0.015)$ & $(0.013)$ \\
CAPACITY & 0.319 & -0.164 & -0.015 \\
& $(0.161)^{* *}$ & $(0.168)^{* *}$ & $(0.147)$ \\
PRIVATE_SECTOR & -0.052 & 0.057 & 0.085 \\
HEAVY_MENTALLY & $(0.052)$ & $(0.050)$ & $(0.051)^{*}$ \\
HEAVY_PHYSICALLY & -0.094 & 0.586 & -0.230 \\
OWN_PLAN & $(0.161)$ & $(0.159)^{* * *}$ & $(0.162)$ \\
PIPELINE & -0.136 & -1.163 & \\
SMALL_PLANT & $(0.355)$ & $(0.446)^{* * *}$ & \\
TEMPORARY & -0.299 & 0.114 & \\
CONSTANT & $(0.586)$ & $(0.397)$ & \\
& -0.149 & -0.439 & \\
\hline
\end{tabular}

Note: Multivariate probit estimation with simulated maximum likelihood. $\mathrm{N}=382$.

Robust standard errors in parentheses. Significance level: *** 1\%, ** 5\%, *10\%

Our third dependent variable, continuing work while retired, is difficult to predict. The only clearly significant effect is that good working capacity has a positive impact. Having anticipated retirement age above 63 does not affect plans to continue working.

The estimated correlations of the first and third and second and third equations are clearly small (-0.09 and -0.10 , respectively). The correlation of the first and second equations (partial retirement and retirement age) is 0.32 , but significant only at 15 per cent level. This indicates that PARTIAL_RETIREMENT might not be endogenous for RETIREMENT_OVER_63. Estimation of the models jointly may still be more efficient than estimation of separate models. 


\subsection{Robustness analysis}

To investigate whether our conclusions are changed if we change the specification of the model, we conducted several additional estimates. Their results are not reported in the tables, but we comment on them briefly.

As a first robustness check we included some additional variables in the model. Instead of age group dummies, we tried including a single dummy for those over 60 years. This did not change our main conclusions. The working conditions variables HEAVY_MENTALLY and HEAVY_PHYSICALLY are somewhat problematic, since a relatively low share individuals in the older age groups have answered in the survey that these are significant problems. Extending the definition of heavy work does not give any significant coefficients for these variables.

As a further robustness check we conducted two other kinds of estimations. We estimated the models as univariate probits. The main differences to the results reported above were that the wage effects in the equation for PARTIAL_RETIREMENT were not as significant, having chronic illness now had a negative and significant effect of RETIRE_OVER_63, and females dummy had a significant negative and the highest education group positive effect on RETIRE_AND_WORK. Otherwise our conclusions were not affected. Further, we used more information on the anticipated retirement age and modelled it as an ordered variable with classes below 63,63 , and over 63 . In the ordered probit estimation of this model ${ }^{18}$ all the other exogenous variables that were significant in Table 2 remained significant, except for the education variables and the highest wage group dummies. On the other hand, CAREER and CAPACITY were now significant with expected signs. Partial retirement was insignificant also in this estimation.

Since the retirement behaviour of men and women may be different (besides different intercepts), we estimated the three-equation probit model separately for them. ${ }^{19}$ Among women, the main differences to the estimates for the whole sample were that part-time pension is more common among those with the highest education level, but the highest wage levels no longer have significant coefficients (as opposed to Table 2 where they were significantly

\footnotetext{
${ }^{18}$ The sample was restricted to those above age 56 and below 63 , since all of the three alternatives are no longer available for the 63 year olds.

${ }^{19}$ We dropped the variable TEMPORARY from these estimations, since in some subgroups the number of temporary workers was fairly small. For example, there are no men who both have a temporary contract and are on part-time pension.
} 
negative). The use of unemployment pension pipeline by the employer had now a significant positive effect on part-time pension among women. Further, aspirations to continue working beyond age 63 are less common among married women. This is understandable since husbands tend to be slightly older than wives and spouses are likely to want to retire at the same time. CAREER and physically heavy work were now significant (with negative coefficients), whereas ILLNESS and mentally heavy work were not. Among men, the most interesting difference to the full sample results were that part-time pension is less likely among married men. Again, this may reflect joint retirement decisions of the spouses who have an age difference.

Since our data is based on a sample of employed persons, there is a potential selection problem. Those who have opted for early retirement e.g. in the form of disability pension are not included in the sample. The remaining individuals may therefore not be a random sample of the age group 56 to 64 . Since we do not observe those who have already retired, a normal selection model cannot be estimated. Since the selection bias is essentially an omitted variable problem (the selection correction term being omitted), we can argue that the problem has been at least partly diminished by having included observables, like health and working capacity, that influence the selection of individuals to early retirement or staying at work.

Bloom and Killingsworth (1985) suggest a method for estimating a selection model using only the observations in the truncated sample. In their model the (single) dependent variable is continuous. However, in our case the dependent variables are binary (and in principle we have a multivariate model). As a robustness check of our estimations we treated the univariate models as linear probability models and estimated them separately with the BloomKillingsworth procedure. In the selection models we included CAPACITY and ILLNESS (but excluded them from the primary models), as well as FEMALE and MARRIED. This estimation did not change our conclusions on the main determinants of the retirement behaviour variables, although the results were somewhat sensitive to the choice of the variables included in the selection model. Especially in the models for RETIRE_OVER_63 and RETIRE_AND_WORK it was difficult to model the selection. In any case, the estimations did not change our conclusions on the impact of part-time pension on retirement age aspirations. Since the model can be estimated only because of the nonlinear functional form and we have treated the primary equations as linear probability models, these results should, however, be treated with caution. 
To summarize our findings, we did not find a significant positive effect of partial retirement on anticipated retirement age in any of the robustness checks. Therefore our conclusion that partial retirement does not seem to lengthen the working life seems robust.

\section{Conclusions}

Optimally, partial retirement is a "double dividend" that satisfies both the needs of individuals and the sustainability of the pension system. Individuals prefer shorter working hours at the age when their working capacity is slowing down. From the point of view of the pension system, the other side of the double dividend rests on the assumption that partial retirement leads to longer working careers.

In this paper we have analyzed the effects of partial retirement in Finland, where part-time pensions have become a popular way of achieving a smooth transition from work to retirement. Employment rates of older workers have risen rapidly, and part of this increase in the employment rates is attributable to this scheme, especially in the age group 60-64. The scheme gives a rather tempting opportunity to ageing workers to reduce their working hours i.e. to move from full-time work to part-time work. It is a convenient way to reduce working hours in the current job, since half of the corresponding loss in wage income is compensated as pension income. Furthermore, while on part-time pension new old-age pension rights accrue both from the part-time work and from the difference between full-time and part-time wage. The costs of the scheme are borne collectively by the whole pension system and not by the employer in question directly.

We have considered three retirement decisions, which we think are related to each other. They are: (i) whether to retire on part-time pension, (ii) whether to continue work beyond the lower age limit of the flexible old-age pension and, (iii) whether to work while on retirement. We have hypothesized a recursive structure in the process how the individuals formulate their retirement plans and aspirations. The decision on part-time retirement is made first (it has already been made before the survey that we have used as our data). Given this decision, the individuals anticipate whether they plan to work beyond the age 63. Further, given their anticipated retirement age, they indicate whether they plan to continue working while on retirement. The corresponding three-equation multivariate probit model was estimated with simulated maximum likelihood. 
The main focus of our interest has been whether the use of part-time pension has a postponing effect on the timing of retirement on the old-age pension. The analysis indicates that being already on part-time pension does not have a significant effect on the probability of thinking about continuing working after age 63 . Our robustness analysis did not alter this result: we did not find a significant positive effect of partial retirement on anticipated retirement age in any of our alternative estimations. Neither did we find a significant effect of anticipated retirement age on future plans to continue working while on retirement.

Our results refer to the concern that being on partial retirement does not increase the probability of preferring to stay longer at work. This gives support to the worries that partial retirement is a tool that helps in increasing the labour force participation of the aging labour force, but at a relatively high cost. 


\section{References}

Abraham, K.G. and Houseman, S.N., 'Work and retirement plans among older Americans', Upjohn Institute Staff Working Paper No. 04-105, 2004

Ajzen, I., 'The theory of planned behavior', Organizational Behavior and Human Decision Processes 50, 1991, 179-211

Benítez-Silva, H. and Dwyer, D.S., 'The rationality of retirement expectations and the role of new information', Review of Economics and Statistics 87, 2005, 587-592

Bernheim, B.D., 'The timing of retirement: A comparison of expectations and realizations', in D.A. Wise (ed.), The Economics of Aging, Chicago: University of Chicago Press, 1989, 335355

Bertrand, M. and Mullainathan, S. 'Do people mean what they say? Implications of subjective survey data', American Economic Review 91, Papers and Proceedings, 2001, 67-72

Bloom, D. E. and Killingsworth, M. R., 'Correcting for truncation bias caused by a latent truncation variable', Journal of Econometrics 27, 1985, 131-135

Börsch-Supan, A., 'The pension reform in Finland', Finnish Centre for Pensions, Working Papers 2005:1

Botazzi, R., Jappelli, T., and Padula, M., 'Retirement expectations, pension reforms and their effect on private wealth accumulation', CEPR Discussion Paper No. 4882, 2005

Cappelari, L. and Jenkins, S. P., 'Multivariate probit regression using simulated maximum likelihood', Stata Journal, 3, 2003, 278-294.

Chan, S. and Stevens, A.H., 'Do changes in pension incentives affect retirement? A longitudinal study of subjective retirement expectations', Journal of Public Economics 88, 2004, 1307-1333

Delsen, L. and Reday-Mulvey, G., 'Potential for gradual retirement and recommendations', in L. Delsen and G. Reday-Mulvey, eds., Gradual Retirement in the OECD Countries, Aldershot: Dartmouth Publishing Co., 1996, 25-44

Disney, R. and Tanner, S., 'What can we learn from retirement expectations data?', Institute for Fiscal Studies, Working Paper W99/17, 1999

Forma, P., Tuominen, E., and Väänänen-Tomppo, I., 'Who wants to continue at work? Finnish pension reform and the future plans of older workers', European Journal of Social Security 7, $2005,227-250$

Gould, R. and Saurama, L., 'From early exit culture to the policy of active ageing - the case of Finland', in T. Maltby, B. de Vroom, M.L. Mirable, and E. Øverbye, eds., Ageing and the Transition to Retirement. A Comparative Analysis of European Welfare States, Aldershot: Ashgate, 2004, 67-92 
Greene, W.H., Econometric Analysis, $5^{\text {th }}$ ed., Upper Saddle River: Pearson Education, 2003

Heckman, J.J., 'Dummy endogenous variables in a simultaneous equation system' Econometrica 46, 1978, 931-959

Ilmakunnas, S. and Takala, M., 'Promoting employment among ageing workers: Lessons from successful policy changes in Finland', Geneva Papers on Risk and Insurance - Issues and Practice 30, 2005, 674-692

Karisalmi, S., 'Epätyypillinen työ, ikääntyvä työntekijä ja työssä jatkaminen' (Atypical work, ageing workers and intentions to continue work), Finnish Centre for Pensions, Discussion Papers 2005:2, 2005

Latulippe, D. and Turner, J. 'Partial retirement and pension policy in industrialized countries', International Labour Review 139, 2000, 179-195

Lehto, A.-M. and Sutela, H., Threats and Opportunities: Findings of Finnish Quality of Work Life Surveys 1977-2003, Helsinki: Statistics Finland, 2005

Mastrogiacomo, M., Retirement, Expectations, and Realizations: Essays on the Netherlands and Italy, Tinbergen Institute Research Series, No. 336, 2004

McGarry, K., 'Health and retirement: Do changes in health affect retirement expectations?', Journal of Human Resources 39, 1999, 624-648

Monfardini, C. and Radice, R., 'Testing exogeneity in the bivariate probit model: a Monte Carlo study', Department of Economics, University of Bologna, mimeo, 2006

OECD (2006), Ageing and Employment Policies. Live Longer, Work Longer, Paris:OECD.

Ruhm, C. J, 'Bridge Jobs and Partial Retirement', Journal of Labor Economics 8, 1990, 482501

Takala, M., 'Osa-aikaeläkeläisten eläkkeet ja ansiot' (Pensions and earnings of partial retirees), Finnish Centre for Pensions, Monisteita 47, 2004

Takala, M., 'Onko osa-aikatyöstä ratkaisuksi työssä jaksamiselle?' (Is part-time work a solution for continuing in working life?), in E. Tuominen, ed., Eläkeuudistus ja ikääntyvien työssä jatkamisaikeet (Pension Reform and Intentions of the Aging to Continue Working), Finnish Centre for Pensions, Reports 37, 2004, 85-129

Takala, M. 'Osa-aikaeläke ja varhennettu vanhuuseläke muuttuvat - nouseeko eläkeikä' (Parttime pension and early old-age pension are changing - what about the retirement age?), in M. Takala and H. Uusitalo, eds., Varhaiseläkkeet muuttuvat - mutta mitten? (Early-retirement schemes are changing - how?), Finnish Centre for Pensions, Reports 30, 2002, 51-66

Wadensjö, E., 'Gradual retirement in Sweden', in L. Delsen and G. Reday-Mulvey, eds., Gradual Retirement in the OECD Countries, Aldershot: Dartmouth Publishing, 1996, 25-44

Wilde, J. 'Identification of Multiple Equation Probit Models with Endogenous Dummy Regressors', Economics Letters 69, 2000, 309-312 


\section{Appendix 1: Description of variables}

\section{Dependent variables}

PARTIAL RETIREMENT

RETIREMENT_OVER_63

RETIRE_AND_WORK

\section{Explanatory variables}

AGE_i

EDUCATION1

EDUCATION2

EDUCATION3

EDUCATION4

FEMALE

MARRIED

WAGE_i

CAREER
Dummy for being on partial retirement or having applied for partial retirement

Dummy for preferring a retirement age of over 63 years. In robustness analysis, preferred retirement age is coded as an ordered variable: below 63, 63, over 63 .

Dummy for planning to continue working while on retirement

Dummies for ages $i=57,58,59,60,61,62$, and 63 (reference group 57)

Dummy for comprehensive education (reference group)

Dummy for upper secondary or vocational education Dummy for polytechnic or lower university degree Dummy for higher university degree Dummy for females Dummy for married or cohabiting Monthly wage group dummies, $i=1, \ldots, 4$. Groups defined as $€ 1900$ or below, $€ 1901-2700, € 2701-3600$, above $€$ 3600. Wage groups are self-reported, but in case of partial retirement, the wage has been calculated from register information on partial pension or previous year's taxable income (see footnote 11).

Years of work experience that has accrued pension 
CAPACITY

ILLNESS

HEAVY_PHYSICALLY

HEAVY_MENTALLY

TEMPORARY

SMALL_PLANT

PIPELINE

OWN_PLAN

PRIVATE_SECTOR
Self-assessment of working capacity. The variable is a score from 0 (total inability to work) to 10 (top working capacity) Dummy for persons suffering from medically diagnosed chronic illness

Dummy for current tasks physically 'very demanding' Dummy for current tasks mentally 'very demanding' Dummy for temporary employment relationship Dummy for employer plant having less than 10 employees Dummy for the use of unemployment pension pipeline at the workplace during the last three years Dummy for having voluntary private pension insurance Dummy for working in the private sector (instead of the state or municipalities) 